\title{
Evaluation of Artemisia amygdalina D. for Anti-Inflammatory and Immunomodulatory Potential
}

\author{
Khan Mubashir, ${ }^{1}$ Bashir A. Ganai, ${ }^{1}$ Khalid Ghazanfar, ${ }^{2}$ Seema Akbar, \\ Akhtar H. Malik, ${ }^{3}$ and Akbar Masood ${ }^{1}$ \\ ${ }^{1}$ Department of Biochemistry, University of Kashmir, Srinagar 190006, India \\ ${ }^{2}$ Regional Research Institute of Unani Medicine, Kashmir University Campus, Srinagar 190006, India \\ ${ }^{3}$ Centre for Biodiversity and Taxonomy (CBT), Department of Botany, University of Kashmir, Srinagar 190006, India
}

Correspondence should be addressed to Bashir A. Ganai; bbcganai@gmail.com

Received 16 August 2013; Accepted 12 September 2013

Academic Editors: J. Meseguer and V. Montinaro

Copyright (C) 2013 Khan Mubashir et al. This is an open access article distributed under the Creative Commons Attribution License, which permits unrestricted use, distribution, and reproduction in any medium, provided the original work is properly cited.

\begin{abstract}
Artemisia amygdalina D. is a critically endangered endemic medicinal plant of Kashmir Himalayas. In the current study antiinflammatory and immunomodulatory activity of the plant was carried out. Carrageenan paw edema model was used to study the potential of the drug in inflammation in Wistar rats. SRBC-specific haemagglutination titre and DTH assays were carried out in Balb/C mice for observing the effect of test drugs on immune system. The plant extracts used as test drugs showed to have anti-inflammatory potential. The methanolic fraction was observed to have the maximum effect on the inhibition of paw edema formation with the inhibitory potential of $42.26 \%$, while in the immunomodulation studies the test drugs were found to have the immunosuppressant activity with methanolic fraction again showing the maximum potential for the suppression of both humoral (55.89\% and $47.91 \%)$ and cell-mediated immunity $(62.27 \%$ and $57.21 \%)$. The plant in total seems to have the anti-inflammatory potential. The suppression of immune system suggests some mechanistic way by which the inhibition of inflammation takes place. Since, in chronic inflammation like arthritis, there is the involvement of immune system, the plant in that way may serve as an alternative for the treatment of such autoimmune diseases.
\end{abstract}

\section{Introduction}

Inflammation is the reaction of living tissues to injury, infection, or irritation. It is an essential protective process preserving the integrity of organisms against physical, chemical, and infective insults. However, it is frequent that the inflammatory response to several insults erroneously leads to the damaging of normal tissues responsible for certain pathological conditions such as heart attacks, septic shocks, and rheumatoid arthritis [1]. One of the early cellular events in inflammation is the migration of leukocytes, primarily neutrophils. This response can be measured by using the neutrophilspecific enzyme myeloperoxidase (MPO), an indicator of neutrophil accumulation [2]. In addition, nitric oxide (NO) and TNF- $\alpha$ produced by macrophages play an important role in inflammation, and NO synthase inhibitors can reverse several classic inflammatory symptoms [3]. TNF- $\alpha$ is a cytokine which plays an important role in inflammation. TNF- $\alpha$ stimulates neutrophils to transcribe and release cytokines and chemokines biosynthesis [4].

In autoimmune diseases, on one hand pathogenic selfreactivity of T cells plays an important role, while on the other hand self-reactivity is needed to regulate autoaggressive responses. Delayed-type hypersensitivity can be elicited in rodents against a variety of antigens such as bacteria, sheep red blood corpuscles (SRBCs), and histocompatibility antigen and is a T-lymphocyte-dependent phenomenon. The arthritogenic $\mathrm{T}$ cells likely migrate to the joints and initiate inflammation in the synovium by recruiting other lymphocytes, monocyte/macrophages, and polymorphonuclear leukocytes [5]. These may release cytokines and other products, which contribute to resorption of bone and destruction of cartilage. Thus, pharmacological inhibition of this leukocyte migration and accumulation in arthritis may have beneficial effects for joint preservation [6]. The most challenging question for the study of rheumatoid arthritis concerns 
the specificity of immune reactions, which indicate and perpetuate the autoimmune pathology. Those reactions are most likely dependent on activated autoreactive $\mathrm{T}$ cells but do also involve certain autoreactive B cells and such immune specific lymphocytes can be anticipated to be involved in both delayed-type hypersensitivity (DTH) and immune complexmediated pathogenic inflammation [7].

Artemisia amygdalina $\mathrm{D}$. is an endemic medicinal plant of Kashmir valley belonging to the family Asteraceae and grows in subalpine region of Kashmir Himalaya and North-West Frontier Province of Pakistan [8]. The plant extract is used locally for the treatment of epilepsy, piles, nervous disorders, cough, cold, fever, and pain [9]. The women folk of the valley use it for amenorrhea and dysmenorrhoea [10]. The major active principles in this plant are the terpenes, $\mathrm{p}$-cymene, and 1,8-cineole [11]. As a consequence of overharvest and deforestation, this plant is considered as the critically endangered endemic species of Kashmir valley [8].

The current study was carried out to evaluate the antiinflammatory potential of this plant and then to study its effect on the immune system.

\section{Materials and Method}

2.1. Collection and Identification of Plant Material. The plant material was procured from Kashmir University Botanical Garden (KUBG) and identified in the Centre of Plant Taxonomy (COPT), Department of Botany, University of Kashmir, India. The specimen is retained in the herbarium of COPT vide Voucher no. 1803.

2.2. Preparation of Extracts. The whole plant (aerial) was washed, cut into small pieces, and shade-dried. The plant material was pulverized into coarse powder and extracted successively using petroleum ether, ethyl acetate, methanol, and water, respectively, by soxhlet extraction. The solvents were allowed to evaporate in a rotary evaporator at $40^{\circ}-45^{\circ} \mathrm{C}$, and the extracts obtained were stored in a refrigerator at $4^{\circ} \mathrm{C}$. The yields of the petroleum ether, ethyl acetate, methanol, and aqueous extracts were $4.8,5.2,5.8$, and $5.3 \%(\mathrm{w} / \mathrm{w})$, respectively.

2.3. Animals. Male albino Wistar rats (120-140 gm) in groups of 4 each were used for anti-inflammatory study. Drugs were prepared in 1\% Tween 20 and administered orally at doses of $250 \mathrm{mg} / \mathrm{kg}$ bw. Diclofenac was used as an anti-inflammatory drug at a dose of $20 \mathrm{mg} / \mathrm{kg}$ (p.o.).

Male Balb/C mice of 8-10 weeks old and weighing 18$22 \mathrm{~g}$, in groups of five each, were used for the immunomodulatory study. Drugs for oral administration were freshly prepared as a homogenised suspension of different extracts of $A$. amygdalina D. at doses of $100 \mathrm{mg} / \mathrm{kg}$ each in $1 \%$ Tween 20 and administered orally, once daily for the duration of the experiment to Balb/C mice. Cyclophosphamide was used as the standard immunosuppressive agent at $50 \mathrm{mg} / \mathrm{kg}$ (p.o.).

The animals were housed under standard laboratory conditions with a temperature of $(25 \pm 2)^{\circ} \mathrm{C}$, relative humidity of $(55 \pm 10) \%$, and $12 / 12 \mathrm{~h}$ light-dark cycles and fed with standard pellet diet (Lipton India Ltd.), and water was given ad libitum. None of the animals was sacrificed throughout the study.

2.4. Chemicals. Tween 20, cyclophosphamide, and diclofenac were purchased from Sigma Chemical Co. (St. Louis, MO, USA). All other reagents used were of analytical grade.

Fresh blood was collected from a healthy sheep in the animal house. Sheep red blood cells (SRBCs) were washed thrice with normal saline adjusted to a concentration of $1 \mathrm{ml}$, containing $5 \times 10^{9}$ cells for immunisation and challenge.

2.5. Experimental Protocols. All experimental protocols and the number of animals used for the experimental work were duly approved by the Institutional Animals Ethics Committee (IAEC); of Indian Institute of Integrative Medicine (CSIR), Canal Road Jammu (CPCSEA registration no. 67/CPCSEA/ 99).

2.6. Carrageenan-Induced Paw Edema. Carrageenan-induced paw edema model [12] was utilized to assess the acute antiinflammatory potential of the test samples. Animals were divided into six groups $(n=4)$. Group I served as control, rats in groups II-V were administered with plant extracts, and group VI was used as positive control. All drugs were given orally $45 \mathrm{~min}$ before carrageenan injection. Carrageenan was prepared in normal saline (1\%), and $0.1 \mathrm{ml}$ was injected into the subplantar region of left hind paw. The volume of both paws was measured with volume differential meter (520-R, IITC Life Science, USA) after $4 \mathrm{~h}$ with the volume of right paw taken as uninjected paw volume. Percent inhibition was calculated by taking mean of the difference of right and left paw oedema, using the formula

$$
\% \text { inhibition }=\frac{C-T}{C} \times 100 \text {, }
$$

where $C$ is mean oedema in the control group and $T$ is mean oedema in the treated group.

2.7. Humoral Antibody Response. The mice were divided into 6 groups, each consisting of 5 animals. Mice in group I (control) were given $1 \%$ Tween $20,0.2 \mathrm{ml} /$ mouse for 14 days. Mice in group II-V were given $100 \mathrm{mg} / \mathrm{kg}$ bw (orally) for 14 days. Mice in group VI were given cyclophosphamide $50 \mathrm{mg} / \mathrm{kg}$ on day 1 and continued for 14 days. The animals were immunised by injecting $200 \mu \mathrm{L}$ of $5 \times 10^{9}$ SRBCs/mL, intraperitoneally (i.p.) on day 1. Blood samples were collected in microliter tubes from individual animals of all the groups by retroorbital vein puncture on day 7 and day 14. The blood samples were centrifuged, and the serum was separated. Then, haemagglutination primary and secondary titres were performed $[13,14]$.

2.8. Delayed-Type Hypersensitivity. A new area of research is the discovery or/and development of immunomodulatory agents that are free from any toxic side effects and can be used for a long duration, resulting in continuous immunoactivation/suppression [15]. Animals were divided into six groups of 5 each. Group I served as sensitized control, as in humoral 
TABLE 1: Effect of different extracts of Artemisia amygdalina D. on Carrageenin-induced paw edema in rats $(\mathrm{mean} \pm \mathrm{SE})(n=4)$.

\begin{tabular}{|c|c|c|c|c|c|c|}
\hline S. no. & Groups & Dose (mg/kg) & Initial paw vol. (mL) & Paw vol. after $4 \mathrm{~h}(\mathrm{~mL})$ & Edema (4 h) & $\%$ age inhibition $(4 \mathrm{~h})$ \\
\hline 1 & Control & NS & $0.95 \pm 0.03$ & $1.9 \pm 0.04$ & $0.95 \pm 0.03^{\mathrm{a}}$ & - \\
\hline 2 & AMT & 250 & $1 \pm 0.00$ & $1.52 \pm 0.05$ & $0.52 \pm 0.05^{\mathrm{b}}$ & 45.26 \\
\hline 3 & AET & 250 & $0.97 \pm 0.05$ & $1.75 \pm 0.06$ & $0.77 \pm 0.05^{\mathrm{b}}$ & 18.95 \\
\hline 4 & APT & 250 & $0.95 \pm 0.04$ & $1.87 \pm 0.09$ & $0.92 \pm 0.07^{\mathrm{ac}}$ & 3.16 \\
\hline 5 & AAQ & 250 & $0.92 \pm 0.02$ & $1.6 \pm 0.04$ & $0.67 \pm 0.05^{b c}$ & 29.47 \\
\hline 6 & Diclo & 20 & $1.07 \pm 0.07$ & $1.52 \pm 0.05$ & $0.45 \pm 0.03^{c}$ & 52.63 \\
\hline
\end{tabular}

Values along the same column with different superscripts are statistically significant to each other using Tukey's HSD test $(P<0.05)$. AMT: methanolic extract; AET: ethyl acetate extract; APT: petroleum ether extract; AAQ: aqueous extract; Diclo: diclofenac.

antibody titre. Mice in group II-V were administered extracts of A. amygdalina after SRBCs' sensitization and once daily for seven days. Cyclophosphamide $(50 \mathrm{mg} / \mathrm{kg}$ ) was administered as standard T-cell suppressor (group VI). The mice were challenged by injecting the same amount of SRBCs intradermally into the right hind footpad, whereas left hind footpad served as control $[16,17]$.

The footpad thickness was measured with sphaeromicrometer (pitch $0.01 \mathrm{~mm}$ ) at 24 and $48 \mathrm{~h}$ of SRBCs' challenge.

\section{Results and Discussion}

3.1. Carrageenan-Induced Paw Edema. Inflammation is a protective process that is essential for the preservation of the integrity of the organism in the event of physical, chemical, and infectious damages. Often, the inflammatory response to severe lesions, erroneously damages normal tissue [18]. The injection of carrageenan into the hind paw of rats elicits an acute inflammatory response characterized by accumulation of fluid (edema). During acute inflammation, serum proteins and leukocytes migrate to areas of tissue injury. Recruitment of cells to inflammatory sites is dependent on the release of vasoactive and chemotactic factors that increase regional blood flow and microvascular permeability and promote the migration of leukocytes from the intravascular space into the tissues [19]. The different extracts tested orally for antiinflammatory activity at a dose of $250 \mathrm{mg} / \mathrm{kg}$ showed decrease in the paw edema after $4 \mathrm{~h}$. Methanolic extract showed maximum inhibition in paw edema (45.26\%) as compared to control followed by aqueous ( $29.47 \%)$, ethyl acetate (18.95\%), and petroleum ether (3.16\%) extracts (Table 1). The inhibition in the paw edema of standard group observed was 52.63\%. The $\%$ inhibition by methanolic and standard drug is very much comparable and is statistically significant at $P<0.05$, while the results obtained in the petroleum ether-treated group are almost same as that of the control group.

3.2. Humoral Antibody Titre. The antibody titre was determined to establish the humoral response against sheep RBC. At neutral $\mathrm{pH}$, red blood cells possess negative ions cloud that makes the cells repel from one another; this repulsive force is referred to as zeta potential. Because of its size and pentameric nature, IgM can overcome the electric barrier and get cross-link red blood cells, leading to subsequent agglutination [20]. The different fractions of A. amygdalina used produced decreased the effect on primary and secondary antibody formation compared to control. But methanolic fraction
TABLE 2: Effect of different extracts of $A$. amygdalina D. on haemagglutination titre in mice (mean $\pm \mathrm{SE})(n=5)$.

\begin{tabular}{lccc}
\hline \multicolumn{4}{c}{ Humoral response } \\
\hline Groups & $\begin{array}{c}\text { Dose } \\
(\mathrm{mg} / \mathrm{kg})\end{array}$ & $\begin{array}{c}\text { Primary } \\
\text { titre }\end{array}$ & $\begin{array}{c}\text { Secondary } \\
\text { titre }\end{array}$ \\
\hline Control & SRBC & $6.8 \pm 0.38^{\mathrm{a}}$ & $7.20 \pm 0.49^{\mathrm{a}}$ \\
Methanolic fraction & 100 & $3.0 \pm 0.41^{\mathrm{c}}$ & $3.75 \pm 0.43^{\mathrm{b}}$ \\
Ethyl acetate fraction & 100 & $3.5 \pm 0.29^{\mathrm{c}}$ & $4.50 \pm 0.26^{\mathrm{b}}$ \\
Petroleum ether fraction & 100 & $6.0 \pm 0.45^{\mathrm{ab}}$ & $7.40 \pm 0.24^{\mathrm{a}}$ \\
Aqueous fraction & 100 & $4.0 \pm 0.89^{\mathrm{bc}}$ & $4.40 \pm 0.24^{\mathrm{b}}$ \\
Cyclophosphamide & 50 & $4.2 \pm 0.58^{\mathrm{bc}}$ & $3.40 \pm 0.24^{\mathrm{b}}$ \\
\hline
\end{tabular}

Values along the same column with different superscripts are statistically significant to each other using Tukey's HSD test $(P<0.05)$.

produced maximum decrease in humoral response followed by ethyl acetate and aqueous fractions at a dose of $100 \mathrm{mg} / \mathrm{kg}$ (Table 2). The observed decrease in primary and secondary antibody titres in methanolic fraction is $55.89 \%$ and $47.91 \%$, ethyl acetate fraction is $48.53 \%$ and $37.5 \%$, and aqueous fraction is $41.17 \%$ and $38.89 \%$, respectively. Petroleum ether fraction showed decrease in primary response (11.76\%) but a slight increase in secondary response $(2.77 \%)$. The immunosuppressant activity shown by the three fractions is very much comparable to cyclophosphamide $50 \mathrm{mg} / \mathrm{kg}$ used as a standard drug inducing $38.23 \%$ and $52.77 \%$, decrease in primary and secondary titres, thus indicating that these fractions of $A$. amygdalina significantly $(P<0.05)$ inhibit antibody formation (Figure 1(a)). The production of primary antibodies was more pronounced as compared to secondary antibodies.

3.3. Delayed-Type Hypersensitivity Response. DTH reaction is characterised by large influxes of nonspecific inflammatory cells, in which the macrophage is a major component. It is a type IV hypersensitivity reaction that develops when antigen activates sensitized $\mathrm{T}$ cells. Activation of $\mathrm{T}$ cells by antigen presented through appropriate antigen-presenting cells results in the secretion of various cytokines including interleukin-2, interferon- $\gamma$, macrophage migration inhibition factor, and tumor necrosis factor- $\beta$ [21]. The T-cell-mediated DTH response to sheep RBC showed a decrease in paw volume in test groups as compared to control group. Out of the different test groups, methanolic fraction-treated group showed maximum decrease in paw volume which is very 


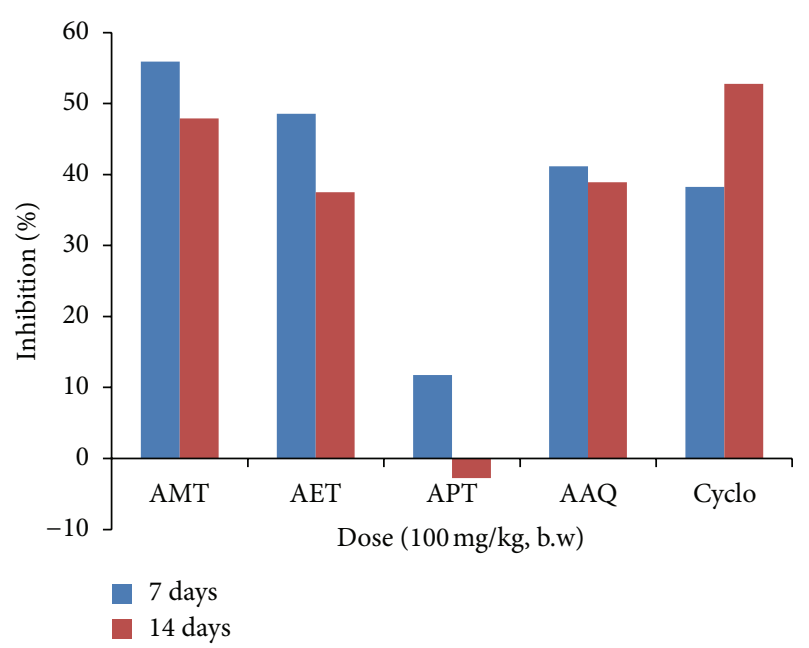

(a)

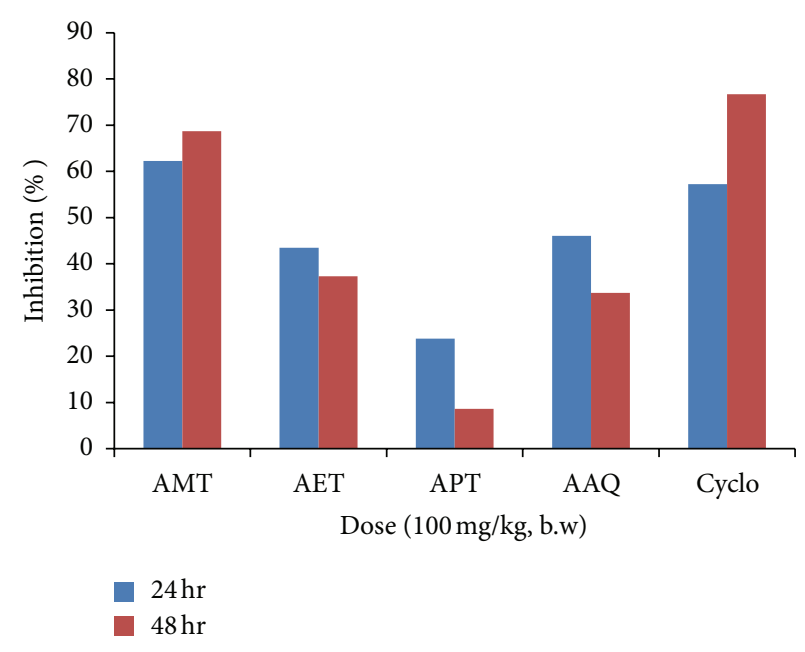

(b)

Figure 1: (a) Graph showing \% age inhibition of primary and secondary response in Balb/C mice by different fractions of A. amygdalina D. (b) Graph showing $24 \mathrm{~h}$ and $48 \mathrm{~h} \%$ age inhibition of cell-mediated response in mice by different fractions of A. amygdalina D.

TABLE 3: Effect of different extracts of Artemisia amygdalina D. on delayed-type hypersensitivity response in mice (mean $\pm \mathrm{SE})(n=5)$.

\begin{tabular}{lccc}
\hline \multicolumn{4}{c}{ DTH assay } \\
\hline Groups & $\begin{array}{c}\text { Dose } \\
(\mathrm{mg} / \mathrm{kg})\end{array}$ & $\begin{array}{c}24 \mathrm{hr} \text { paw } \\
\text { thickness } \\
(\mathrm{mm})\end{array}$ & $\begin{array}{c}48 \mathrm{hr} \text { paw } \\
\text { thickness } \\
(\mathrm{mm})\end{array}$ \\
\hline Control & SRBC & $0.6825 \pm 0.04^{\mathrm{a}}$ & $0.335 \pm 0.021^{\mathrm{a}}$ \\
Methanolic fraction & 100 & $0.2575 \pm 0.02^{\mathrm{c}}$ & $0.105 \pm 0.012^{\mathrm{d}}$ \\
Ethyl acetate fraction & 100 & $0.386 \pm 0.04^{\mathrm{bc}}$ & $0.21 \pm 0.023^{\mathrm{c}}$ \\
Petroleum ether fraction & 100 & $0.52 \pm 0.04^{\mathrm{b}}$ & $0.306 \pm 0.021^{\mathrm{b}}$ \\
Aqueous fraction & 100 & $0.368 \pm 0.032^{\mathrm{c}}$ & $0.222 \pm 0.027^{\mathrm{c}}$ \\
Cyclophosphamide & 50 & $0.292 \pm 0.032^{\mathrm{c}}$ & $0.078 \pm 0.006^{\mathrm{d}}$ \\
\hline
\end{tabular}

Values along the same column with different superscripts are statistically significant to each other using Tukey's HSD test $(P<0.05)$.

much comparable to the results seen in cyclophosphamidetreated group used as standard drug (Table 3). The percentage decrease in edema formation in methanolic fractiontreated group and standard group observed is $62.27 \%$ and $68.65 \%$ and $57.21 \%$ and $76.71 \%$ after 24 and $48 \mathrm{~h}$, respectively (Figure 1(b)). The results observed in test groups were very much significant $(P<0.05)$ compared to the control group.

\section{Conclusion}

Advances made in recent years in order to understand the cellular and molecular bases of immune response and the identification of small peptides capable of regulating this process gave us understanding to alter the immune response in favour of healthy state [22]. The therapeutic efficiency of some herbs may, in part, be mediated via their influence on the immune response, since some of these plants can affect the immune reactions through their anti-inflammatory actions [23]. Similar type of results was observed in the current study of $A$. amygdalina. The plant showed anti-inflammatory and also immunosuppressive activity. Based on the above results and analysis, it can be concluded that A. amygdalina has the potential to suppress cell-mediated immunity as well as humoral immunity, and it may be a potential therapeutic candidate in several immunostimulant clinical conditions. From the current study, it can be said that this plant may be a good resource of bioactive components especially flavonoids which have been found to have the immunomodulatory and antiinflammatory activity [24]. Further detailed studies on its mode of immune action and active constituent's isolation are in progress.

\section{Conflict of Interests}

The authors declare that they have no conflict of interests.

\section{Acknowledgment}

The authors are highly thankful to the Indian Institute of Integrative Medicine (IIIM), Jammu, India, for providing the facilities in accomplishing this research work.

\section{References}

[1] R. R. Habashy, A. B. Abdel-Naim, A. E. Khalifa, and M. M. AlAzizi, "Anti-inflammatory effects of jojoba liquid wax in experimental models," Pharmacological Research, vol. 51, no. 2, pp. 95105, 2005.

[2] J. L. Goulet, J. N. Snouweart, A. M. Latour, and T. M. Coffman, "Altered inflammatory responses in leukotriene-deficient mice," Proceedings of the National Academy of Sciences of the United States of America, vol. 91, pp. 12852-12856, 1994.

[3] A. R. Amin, P. Vyas, M. Attur, and J. Leszcynsca-piziak, "The mode of action of aspirin-like drugs: effect on inducible nitric oxide synthase," Proceedings of the National Academy of Sciences of the United States of America, vol. 92, no. 17, pp. 7926-7930, 1995. 
[4] P. T. Marucha, R. A. Zeff, and D. L. Kreutzer, "Cytokine-induced Il-1 $\beta$ gene expression in the human polymorphonuclear leukocyte: transcriptional and post-transcriptional regulation by tumor necrosis factor and Il-1," Journal of Immunology, vol. 147, no. 8, pp. 2603-2608, 1991.

[5] J. X. Gao and A. C. Issekutz, "The effect of ebselen on T-lymphocyte migration to arthritic joints and dermal inflammatory reactions in the rat," International Journal of Immunopharmacology, vol. 16, no. 4, pp. 279-287, 1994.

[6] J. X. Gao and A. C. Issekutz, "The effect of ebselen on polymorphonuclear leukocyte migration to joints in rats with adjuvant arthritis," International Journal of Immunopharmacology, vol. 15, no. 7, pp. 793-802, 1993.

[7] R. Holmdahl, J. Mo, C. Nordling et al., "Collagen induced arthritis: an experiment model for rheumatoid arthritis with involvement of both DTH and immune complex mediated mechanisms," Clinical and Experimental Rheumatology, vol. 7, supplement 3, pp. S51-S55, 1989.

[8] A. R. Dar, G. H. Dar, and Z. Reshi, "Conservation of Artemisia amygdalina: a critically endangered, endemic plant species of Kashmir Himalayas," Endangered Species Update, vol. 23, pp. 34-39, 2006.

[9] R. Rasool, B. A. Ganai, A. N. Kamili, and S. Akbar, "Antioxidant potential in callus culture of Artemisia amygdalina D.," Natural Product Research, vol. 26, no. 22, pp. 2103-2106, 2012.

[10] M. Qaisar, “Asteraceae," Flora of Pakistan, vol. 207, pp. 120-121, 2006.

[11] M. A. Rather, B. A. Ganai, A. N. Kamili et al., "Comparative GCFID and GC-MS analysis of the mono and sesquiterpene secondary metabolites produced by the field grown and micropropagated plants of Artemisia amygdalina D.," Acta Physiologiae Plantarum, vol. 34, no. 3, pp. 885-890, 2012.

[12] C. A. Winter, E. A. Risley, and G. W. Nuss, "Carrageenininduced edema in hind paw of the rat as an assay for antiiflammatory drugs," Proceedings of the Society for Experimental Biology and Medicine, vol. 111, pp. 544-547, 1962.

[13] D. P. Bhagwat, M. D. Kharya, S. Bani et al., "Immunosuppressive properties of Pluchea lanceolata leaves," Indian Journal of Pharmacology, vol. 42, no. 1, pp. 21-26, 2010.

[14] M. Thakur, P. Connellan, M. A. Deseo, C. Morris, and V. K. Dixit, "Immunomodulatory polysaccharide from chlorophytum borivilianum roots," Evidence-Based Complementary and Alternative Medicine, vol. 2011, Article ID 598521, 7 pages, 2011.

[15] P.-F. Su, V. Staniforth, C.-J. Li et al., "Immunomodulatory effects of phytocompounds characterized by in vivo transgenic human GM-CSF promoter activity in skin tissues," Journal of Biomedical Science, vol. 15, no. 6, pp. 813-822, 2008.

[16] K. Mangathayaru, M. Umadevi, and C. U. Reddy, "Evaluation of the immunomodulatory and DNA protective activities of the shoots of Cynodon dactylon," Journal of Ethnopharmacology, vol. 123, no. 1, pp. 181-184, 2009.

[17] M. G. Jayathirtha and S. H. Mishra, "Preliminary immunomodulatory activities of methanol extracts of Eclipta alba and Centella asiatica," Phytomedicine, vol. 11, no. 4, pp. 361-365, 2004.

[18] A. Lunardelli, C. E. Leite, M. G. S. Pires, and J. R. de Oliveira, "Extract of the bristles of Dirphia sp. increases nitric oxide in a rat pleurisy model," Inflammation Research, vol. 55, no. 4, pp. 129-135, 2006.

[19] A. F. Suffredini, G. Fantuzzi, R. Badolato, J. J. Oppenheim, and N. P. O'Grady, "New insights into the biology of the acute phase response," Journal of Clinical Immunology, vol. 19, no. 4, pp. 203$214,1999$.
[20] J. Kuby, Immunology, W.H. Freeman, New York, NY, USA, 2nd edition, 1994.

[21] P. W. Askenase and M. Van Loveren, "Delayed-type hypersensitivity: activation of mast cells by antigen-specific T-cell factors initiates the cascade of cellular interactions," Immonology Today, vol. 4, no. 9, pp. 259-264, 1983.

[22] R. C. Dutta, "Peptide immunomodulators versus infection; an analysis," Immunology Letters, vol. 83, no. 3, pp. 153-161, 2002.

[23] Z. Amirghofran, M. Azadbakht, and M. H. Karimi, "Evaluation of the immunomodulatory effects of five herbal plants," Journal of Ethnopharmacology, vol. 72, no. 1-2, pp. 167-172, 2000.

[24] P. Hodek, P. Trefil, and M. Stiborová, "Flavonoids-potent and versatile biologically active compounds interacting with cytochromes P450," Chemico-Biological Interactions, vol. 139, no. 1, pp. 1-21, 2002. 


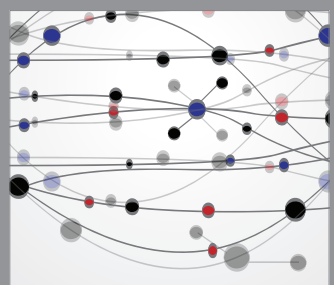

The Scientific World Journal
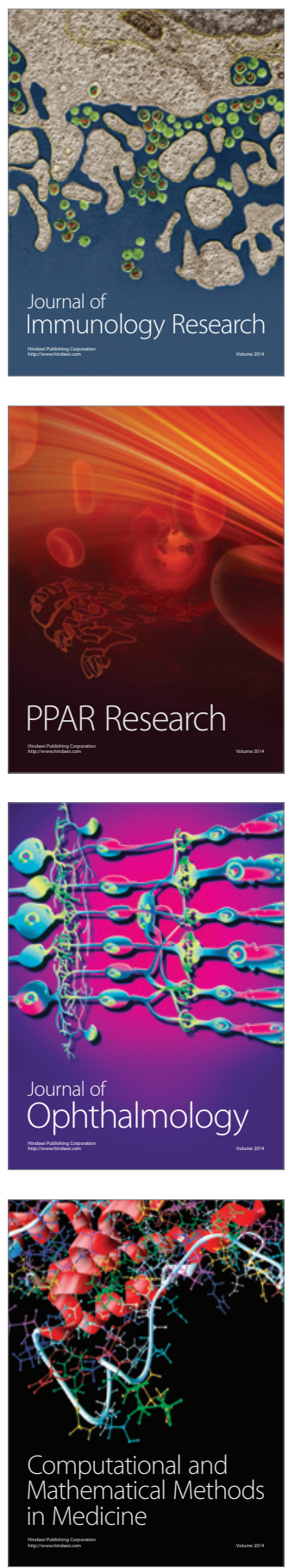

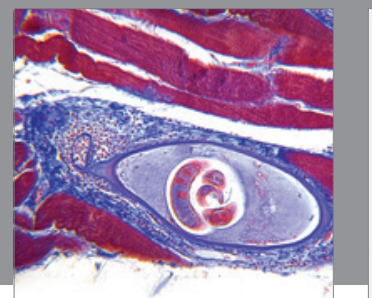

Gastroenterology

Research and Practice
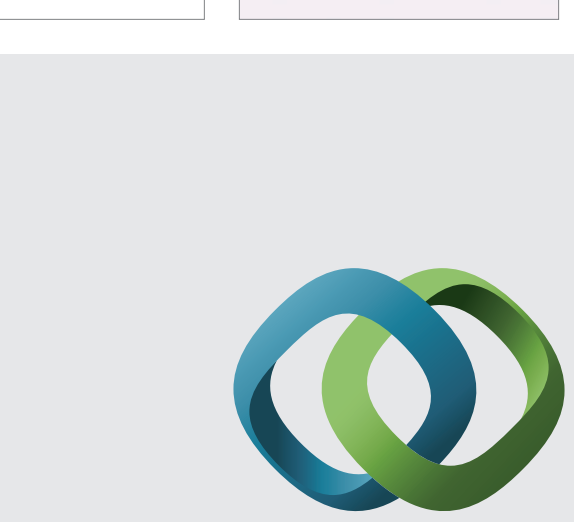

\section{Hindawi}

Submit your manuscripts at

http://www.hindawi.com
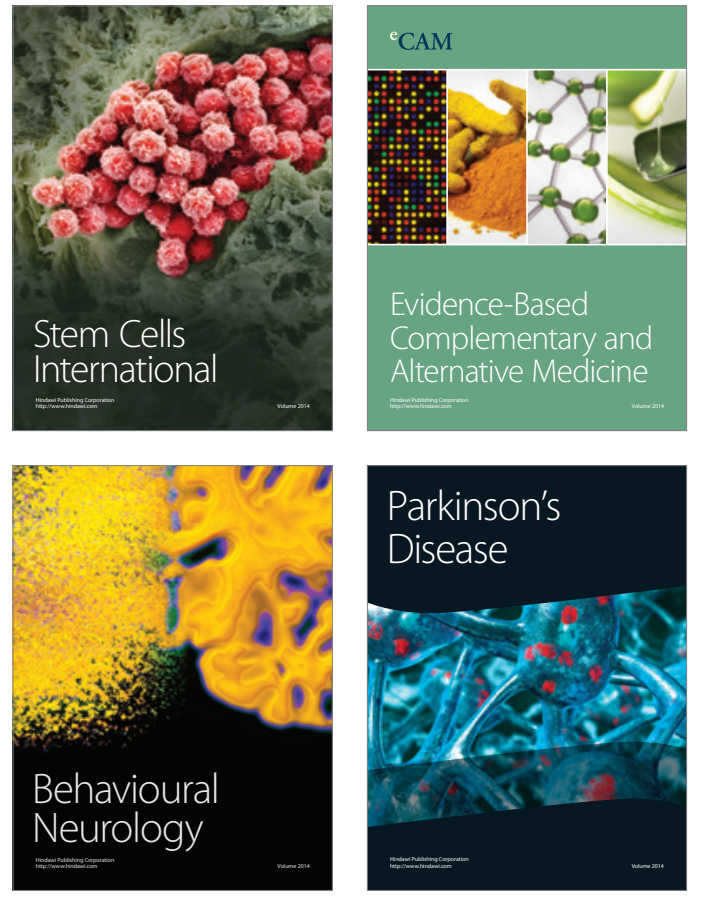
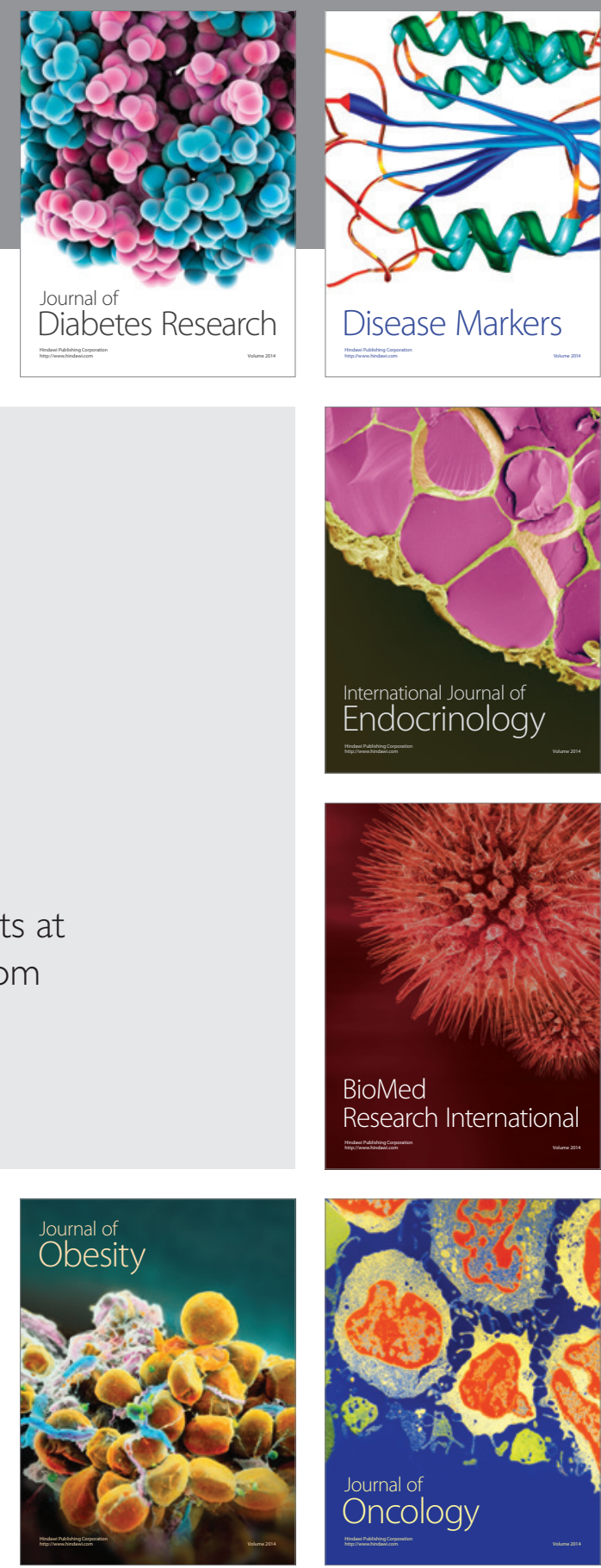

Disease Markers
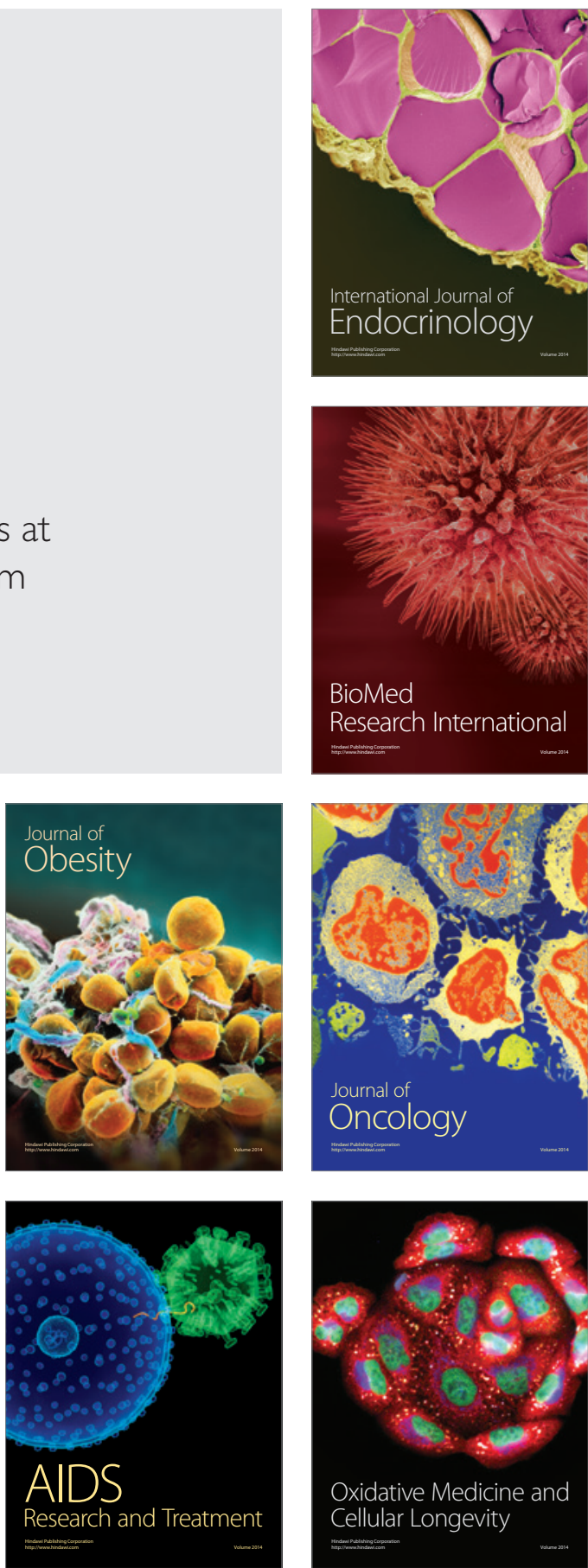